\title{
MANAJEMEN KETATAUSAHAAN/SISTEM INFORMASI
}

Disusun Untuk Memenuhi Tugas Mata Kuliah Manajemen Sekolah

DOSEN PENGAMPU :

Wahyu Bagja Sulfemi, M.Pd



Disusun oleh :

Sopi Nursyaadah

0142S1A018011

STKIP MUHAMMADIYAH BOGOR

PROGRAM STUDI ADMINISTRASI PENDIDIKAN

TAHUN 2019 


\section{A. Pengertian Manajemen}

- Process of working with and through others to accomplish organizational goals efficiently (Sergiovanni dkk, 1987)

- Metode yang digunakan administrator dalam melaksanakan tugas-tugas tertentu untuk mencapai tujuan tertentu. (Sulfemi : 2019)

B. Pengertian Ketatausahaan

Pengertian Tata Usaha menurut para ahli :

- Suatu kegiatan pencatatan dan penyusunan berbagai macam keterangan. Tujuannya adalah agar keterangan-keterangan tersebut bisa dipergunakan secara langsung sebagai bahan atau sumber informasi bagi siapa saja yang membutuhkan, khususnya pimpinan organisasi/perusahaan yang bersangkutan. (saiman : 2002)

- Serangkaian aktivitas penghimpunan, pencatatan, pengolahan, penggandaan, pengiriman dan penyimpanan berbagai macam keterangan yang dibutuhkan dalam setiap organisasi. (The Liang Gie : 1996)

- Kegiatan menghimpun, mengadakan, mencatat, menggandakan, menyimpan serta mengirim berbagai data dan informasi yang berguna untuk mewujudkan tugas pokok organisasi. (Nawawi \& Martini: 1996)

\section{Pengertian Sistem Infomasi}

Sistem Informasi Manajemen adalah seperangkat prosedur gabungan yang mengumpulkan dan menghasilkan data yang andal, relavan dan teroganisir dengan baik yang mendukung proses pengambilan keputusan suatu organisasi.

D. Jenis Laporan Kependidikan

Dalam preakter sistem administrasinasional pendidikan, pelaporan telah menjadi bagian yang terlembagakan dalam arti dari segala sesuatunya 
ditetapkan dengan ketentuan yang diberlakukan untuk satuan-satuan organisasi yang ada. Sejalan dengan itu menurut Keputusan Menteri Pendidikan dan Kebudayaan tanggal 19 Januari 1983 Nomor 050/0/1983, laporan dan pertanggungjawaban pelaksanaan tugas dan fungsi setiap satuan organisasi.

Dalam hal ini jenis yang dikenal terbagi dalam laporan berkala dan laporan incidental. Laporan berkala meliputi laporan tengah tahunan dan laporan tahunan, laporan data statistik, laporan supervisi pendidikan, dan laporan berkala lainnya. Sedangkan laporan incidental adalah laporan yang perlu disampaikan berhubungan dengan adanya kasus atau permasalahan tertentu.

E. Ruang Lingkup Laporan Kependidikan

Adapun ruang lingkup laporan pendidikan, khususnya untuk persekolahan meliputi tugas pokok lembaga kependidikan sekolah, yaitu :

- Program pengajaran

- Kesiswaan

- Kepegawaian

- Keuangan

- Peralatan pengajaran

- Gedung dan perlengkapan sekolah

- Surat-menyurat

- Perpustakaan

- Pembina kesiswaan, dan

- Hubungan sekolah dan masyarakat

F. Fungsi Pokok Tata Usaha Sekolah

a) Kepala Tata Usaha

- Perencanaan administrasi program dan anggaran

- Koordinator administrasi ketatausahaan 
- Pengelola administrasi program

- Penyusun laporan dan anggaran

- Pembina staff

b) Tenaga Administrasi

- Administrasi kepegawaian

- Melaksanakan prosedur dan mekanisme pegawai

- Merencanakan kebutuhan pegawai

- Menilai dan membina staff

- Administrasi keuangan

- Melaksanakan administrasi keuangan sekolah meliputi keuangan rutin / dana komite sekolah / bantuan. Biasanya tugas ini dilakukan atau dirangkap oleh kepla tata usaha.

- Administrasi saran dan prasarana

- Menyusun daftar kebutuhan sarana dan prasarana

- Mencatat dan menginventarisir sarana sekolah

- Menyimpan dokumen kepemilikan

- Membuatbdaftar inventaris ruang, dll

- Administrasi humas

- Membantu kegiatan komite sekolah

- Menjalin kerjasama dengan pemerintah dan lembaga masyarakat sebagai stakeholders

- Mencatat dan mendokumentasikan proses kegiatan kehumasan

- Mempromosikan sekolah dan mengkoordinasikan penelusuran tamatan

- Administrasi persuratan dan kearsipan

- Mengelola surat masuk dan surat keluar

- Menggandakan surat

- Mengelola buku ekspedisi persuratan

- Memelihara dan menata kearsipan dokumen

- Administrasi kesiswaan

- Membuat daftar nomor induk siswa 
- Menyusun daftar kegiatan siswa

- Membuat usulan peserta ujian

- Menginventarisir daftar lulusan

- Mentimpan daftar nilai (leger)

- Menginventarisir pendaftaran siswa baru

- Administrasi layanan khusus

- Melaksanakan fungsi koordinator layanan khusus seperti penjaga sekolah, tukang kebun, dll.

- Teknologi informasi dan komunikasi

- Koordinator layanan data dan informasi seperti mengakses data, mendokumentasikan administrasi, dan menginformasikan serta mempromosikan.

G. Contoh kegiatan Manajemen Sekolah Manajemen Ketenagaan

a) Perencanaan

- Analisis pekerjaan disekolah

- Penyusunan formasi guru dan pegawai

- Perencanaan dan pengadaan guru dan pegawai baru

b) Pengorganisasian

- Pembagian tugas guru dan pegawai

c) Pengerahan

- Pembinaan profesionalisme guru dan pegawai

- Pembinaan karier guru dan pegawai

- Pembinaan kesejahteraan guru dan pegawai

- Pengaturan perpindahan dan pemberhentian guru dan pegawai

d) Pengawasan

- Pemantauan kinerja guru dan pegawai

- Penilaian kinerja guru dan pegawai 
H. Contoh kegiatan Manajemen Sekolah Ketatalaksanaan dan Manajemen Sistem Informasi

a) Perencanaan

- Perencanaan sistem ketatalaksanaan

- Perencanaan alur ketatalaksanaan

- Analisis manajemen sistem informasi sekolah

b) Pengorganisasian

- Pengadaan sistem ketatalaksanaan

- Pengadaan sistem informasi berbasis online

c) Pengerahan

- Implementasi sistem ketatalaksanaan

- Pelaksanaan sistem informasi keuangan berbasis online

d) Pengawasan

- Pemantauan ketatalaksanaan

- Pemantauan sistem informasi sekolah

- Penilaian kinerja sistem informasi sekolah 


\section{KESIMPULAN}

Manajemen adalah Metode yang digunakan administrator dalam melaksanakan tugas-tugas tertentu untuk mencapai tujuan tertentu. (Sulfemi : 2019). Suatu kegiatan pencatatan dan penyusunan berbagai macam keterangan. Tujuannya adalah agar keterangan-keterangan tersebut bisa dipergunakan secara langsung sebagai bahan atau sumber informasi bagi siapa saja yang membutuhkan, khususnya pimpinan organisasi/perusahaan yang bersangkutan. (saiman : 2002).

Sistem Informasi Manajemen adalah seperangkat prosedur gabungan yang mengumpulkan dan menghasilkan data yang andal, relavan dan teroganisir dengan baik yang mendukung proses pengambilan keputusan suatu organisasi. 


\section{DAFTAR PUSTAKA}

- Sulfemi : 2019 manajemen sekolah

- http://www.definisimenurutparaahli.com/pengertian-tata-usaha/

- https://cpssoft.com/blog/manajemen/definisi-sistem-informasi-

manajemen-fungsi-kategori-dan-manfaatnya/

- http://fahmimuh13.blogspot.com/2012/12/v-

behaviorurldefaultvmlo.html

- https://mudahsma.blogspot.com/2016/12/pengertian-dan-fungsi-tatausaha-sekolah.html 


\section{Soal Manajemen Ketatausahan/Sistem Informasi}

\section{Pilihan Ganda !}

1. "Metode yang digunakan administrator dalam melaksanakan tugas-tugas tertentu untuk mencapai tujuan tertentu' merupakan pengertian dari.....
a. Tata Usaha
c. Manajemen
b. Sistem Informasi
d. Sekolah

2. "Serangkaian aktivitas penghimpunan, pencatatan, pengolahan, penggandaan, pengiriman dan penyimpanan berbagai macam keterangan yang dibutuhkan dalam setiap organisasi” merupakan pernyataan dari....
a. Sergiovanni dkk, 1987
c. Sulfemi : 2019
b. Nawawi \& Martini: 1996
d. The Liang Gie : 1996

3. "Process of working with and through others to accomplish organizational goals efficiently" merupakan pernyataan dari .....
a. Sergiovanni dkk, 1987
c. The Liang Gie : 1996
b. Sulfemi : 2019
d. saiman : 2002

4. "Seperangkat prosedur gabungan yang mengumpulkan dan menghasilkan data yang andal, relavan dan teroganisir dengan baik yang mendukung proses pengambilan keputusan suatu organisasi” pengertian dari .....
a. Sekolah
c. Tata usaha
b. Sistem Informasi
d. Manajemen

5. Jenis Laporan kependidikan terbagi menjadi .....
a. 3
c. 1
b. 5
d. 2

6. Keputusan Menteri Pendidikan dan Kebudayaan tanggal 19 Januari 1983 Nomor....
a. $050 / 0 / 1983$
c. $050 / 0 / 1993$
b. $050 / 0 / 1938$
d. $060 / 0 / 1983$ 
7. Laporan tengah tahunan dan laporan tahunan, laporan data statistik, laporan supervisi pendidikan termasuk kedalam jenis laporan .....
a. Laporan incidental
c. Laporan kependidikan
b. Laporan berkala
d. Laporan permasalahan

8. Berikut ini yang termasuk jenis laporan incidental adalah.....
a. Laporan tengah tahunan
b. Laporan kasus / permasalahan
c. Laporan data statistik
d. Laporan supervisi

9. Ada berapa jumlah Tugas pokok lembaga kependidikan sekolah .....
a. 8
c. 10
b. 9
d. 11

10. Yang tidak termasuk kedalam tugas pokok lembaga kependidikan sekolah adalah .....
a. Kesiswaan
b. Kepegawaian
c. Keuangan
d. Orangtua

\section{Uraian !}

1. Jelaskan pengertian tatausaha menurut saiman : 2002!

2. Sebutkan yang termasuk kedalam ruang lingkup laporan kependidikan !

3. Sebutkan fungsi pokok kepala Tata Usaha!

4. Sebutkan perencanaan dan pengorganisasian contoh kegiatan manajemen sekolah manajemen Ketenagaan!

5. Sebutkan perencanaan dan pengorganisasian kegiatan Manajemen Sekolah Ketatalaksanaan dan Manajemen Sistem Informasi! 


\section{Kunci Jawaban}

\section{Pilihan Ganda}

1. C 6. A

2. D 7. B

3. A 8. B

4. B 9. C

5. D 10. D

\section{Uraian}

1. Suatu kegiatan pencatatan dan penyusunan berbagai macam keterangan. Tujuannya adalah agar keterangan-keterangan tersebut bisa dipergunakan secara langsung sebagai bahan atau sumber informasi bagi siapa saja yang membutuhkan, khususnya pimpinan organisasi/perusahaan yang bersangkutan.

2. Program pengajaran, Kesiswaan, Kepegawaian, Keuangan, Peralatan pengajaran, Gedung dan perlengkapan sekolah, Surat-menyurat , Perpustakaan, Pembina kesiswaan, dan Hubungan sekolah dan masyarakat.

3. Perencanaan administrasi program dan anggaran, Koordinator administrasi ketatausahaan, Pengelola administrasi program, Penyusun laporan dan anggaran, Pembina staff

4. -Perencanaan

a. Analisis pekerjaan disekolah

b. Penyusunan formasi guru dan pegawai

c. Perencanaan dan pengadaan guru dan pegawai baru

-Pengorganisasian

d. Pembagian tugas guru dan pegawai

5. -Perencanaan 
a. Perencanaan sistem ketatalaksanaan

b. Perencanaan alur ketatalaksanaan

c. Analisis manajemen sistem informasi sekolah

-Pengorganisasian

d. Pengadaan sistem ketatalaksanaan

e. Pengadaan sistem informasi berbasis online 